\title{
Perancangan Website untuk Menentukan Produk Paling Banyak Terjual di Bengkel Man Motor Metode TOPSIS
}

\author{
Vienne Anggelica Kurnia ${ }^{1}$, Aldo Erianda ${ }^{2}$, Dwiny Meidelfi ${ }^{3}$ \\ 1,2,3 Teknologi Informasi, Politeknik Negeri Padang, Padang, Indonesia \\ ${ }^{1}$ vienneanggelica082@gmail.com \\ 2 aldoerianda@pnp.ac.id \\ ${ }^{3}$ dwinymeidelfi@pnp.ac.id
}

Diterima 16 September 2020

Disetujui 18 November 2020

\begin{abstract}
Decision support system, or DSS, is a system to support decision making process. One commonly used method is TOPSIS. It is a method for decision making on multi-criteria issues, and is one of the simplest and easiest to understand. One of the functions of TOPSIS is to determine the most sold products. It requires a programming language called PHP to implement it on Website. PHP is a server-side programming language, so, all processes are conducted on server, then given to customers. Further, it requires a database for storing the data and software to manage the database is MySQL.
\end{abstract}

Index Terms-DSS, MySQL, PHP, TOPSIS, website

\section{PENDAHULUAN}

Dalam era yang modern seperti saat sekarang ini, teknologi dapat dimanfaatkan untuk menyelasaikan berbagai macam persoalan. Seperti sistem pendukung keputusan atau disebut juga dengan SPK. Dengan adanya teknologi seperti itu bisa membantu untuk menyelasaikan persoalan dengan cepat dan meminimalisir pengeluaran biaya.

Man Motor merupakan salah satu bengkel motor yang ada di Belimbing memiliki banyak konsumen, sehingga diperlukan pencatatan yang detail terhadap barang-barang yang terjual. Saat ini proses pencatatan dan penentuan produk yang terlaris masih dilakukan secara manual. Sehingga jika terjadi kesalahan perhitungan, maka informasi yang dihasilkan tidak tepat.

Dari permasalahan tersebut maka paper ini memberikan solusi yaitu berupa aplikasi website yang berfungsi untuk menentukan produk mana yang paling sering terjual dengan memanfaatkan metode TOPSIS.

\section{A. $\quad$ SPK (Sistem Pendukung Keputusan)}

Sistem pendukung keputusan atau dalam bahasa Inggris Decesion Support System adalah bagian dari sistem informasi yang digunakan untuk pendukung pengambilan keputusan. Sistem pendukung keputsan atau SPK digunakan oleh perusahaan atau organisasi sebagai bahan pertimbangan untuk melakukan sesuatu. SPK juga dapat diartikan sebagai suatu sistem informasi spesifik yang ditunjukan untuk membantu manajemen dalam mengambil keputusan yang berkaitan dengan persoalan yang bersifat semi terstruktur (hukum sebab-akibat dari adanya suatu variabel belum pasti atau bukan suatu rutinitas) [1].

Secara umum sistem pendukung keputusan didefinisikan sebagai sistem yang memiliki kemampuan untuk menyesaikan suatu masalah dan mampu untuk mengkomunikasikan untuk masalahmasalah semi-terstruktur. Sedangkan definisi dari sistem pendukung keputusan secara khusus yaitu sistem yang diperuntukan untuk manajer maupun sekelompok manajer dalam memecahkan masalah dengan cara memberikan informasi atau usulan menuju pada keputusan tertentu [2].

Karakteristik dari sistem pendukung keputusan yaitu [2]:

1. Mendukung seluruh kegiatan organisasi.

2. Mendukung beberapa keputusan yang saling berinteraksi.

3. Dapat digunakan berulang kali dan bersifat konstan.

4. Terdapat dua komponen utama, yaitu data dan model.

5. Menggunakan data ekternal maupun internal.

6. Memiliki kemampuan what-if analysis dan goal seeking analysis.

7. Menggunakan beberapa model kuantitatif.

\section{B. MADM (Multi Attribute Decision Making)}

MADM digunakan untuk menyelesaikan masalahmasalah dalam ruang diskrit. Oleh karena itu, pada MADM biasanya digunakan untuk melakukan penilaian atau seleksi terhadap beberapa alternatif 
dalam jumlah yang terbatas. MADM menyeleksi alternatif terbaik dari sejumlah alternatif. Salah satu metode penyelesaian masalah MADM yaitu TOPSIS [3].

Multi Attribute Decision Making (MADM) adalah sebuah metode yang berfungsi untuk mencari alternatif optimal dari sejumlah alternatif dengan kentetuan tertentu. Hal yang paling utama yang perlu diketahui dari MADM adalah menentukan nilai bobot untuk masing-masing atribut kemudian dilanjutkan ke proses perankingan untuk menyeleksi alternatif yang sudah diberikan [4].

\section{TOPSIS}

Metode TOPSIS pertama kali diperkenalkan oleh Yoon dan Hwang pada 1981. Metode TOPSIS digunakan untuk pengambilan keputusan terhadap persoalan multi kriteria. Alasan menggunakan metode ini yaitu konsepnya sederhana dan mudah dipahami. Prinsip dari metode topsis adalah alternatif yang dipilih harus memiliki jarak terdekat dari solusi ideal positif dan jarak terpanjang dari solusi ideal negatif dari sudut pandang geometris dengan menggunakan jarak Euclidean untuk menentukan kedekatan relatif dari suatu alternatif dengan solusi optimal [3]. Menurut Amelia Nur Fitriana, metode TOPSIS merupakan salah satu metode untuk membantu proses pengambilan keputusan yang optimal untuk menyelesaikan masalah keputusan secara praktis [5].

Langkah-langkah yang digunakan dalam metode TOPSIS adalah [6]:

1. Membuat matriks keputusan yang ternormalisasi.

2. Membuat matriks bobot ternormalisasi.

3. Menghitung matriks solusi ideal positif dan matriks solusi ideal negatif.

4. Menghitung jarak untuk setiap alternatif keputusan.

5. Menghitung nilai preferensi untuk setiap alternatif.

\section{D. $P H P$}

PHP (Hypertext Preprocessor) adalah skrip pemograman yang berada pada sisi server dan di eksekusi langsung oleh server. Fungsi dari PHP yaitu menerima, mengolah dan menampilkan data ke sebuah situs atau website. Data diletakan di sebuah database server kemudian ditampilkan ke browser klien. Dengan demikian PHP dapat membuat website menjadi dimanis karena data yang ditampilkan dapat berubah sesuai permintaan [7].

\section{E. $M y S Q L$}

MySQL adalah sebuah database server yang sangat terkenal, karena MySQ1 menggunakan bahasa SQL.
SQL merupakan bahasa untuk mengakses database. Mysql bersifat free dengan lisensi GNU General Public License (GPL). Dengan demikian MySQL dapat digunakan secara bebas tanpa takut dengan lisensi yang ada. MySQL termasuk kedalam RDBMS (Relational Database Management System) [8].

\section{F. UML (Unified Modelling Language)}

UML (Unified Modelling Language) merupakan salah satu standar bahasa yang digunakan di dunia industri untuk mendefenisikan requirement, membuat analisis dan desain, serta menggambarkan arsitektur dalam pemrograman berorientasi objek [9].

\section{G. Use Case}

Merupakan diagram yang menggambarkan actor, use case dan relasinya sebagai suatu urutan tindakan yang memberikan nilai terukur untuk aktor. Use Case diagram biasanya miliki gambar elips horizontal dan orang. Elips berfungsi untuk mewakili aktivitas, sedangkan orang mewakili jenis pengguna [10].

\section{H. Activity Diagram}

Acitivity diagram berfungsi untuk mengambarkan aktifitas-aktifitas objek, state dan event. Dengan kata lain, acitivty diagram memiliki fungsi untuk mengambarkan prilaku sistem dalam sebuah aktivitas [10].

\section{METODOLOGI}

\section{A. Analisas Sistem}

Untuk melakukan analisis permasalahan metode yang digunakan adalah kerangka PIECES. Berikut langkah-langkah pembuatan kerangka PIECES:

1. Performance (Kinerja)

Untuk proses pembuatan laporan maupun penetuan produk yang paling laku memerlukan waktu yang cukup lama.

2. Information (Informasi)

Informasi yang dihasilkan saat ini masih kurang detail dan tidak lengkap. Dan untuk penyajianya masih secara manual.

\section{Economics (Ekonomi)}

Untuk pembuatan laporan memerlukan biaya tambahan seperti pembelian kertas dan biaya operasional lainya.

4. Control (Kontrol atau Keamanan)

Informasi yang dihasilkan bisa saja hilang, terkena air ataupun terbakar. Karena informasi yang dibuat hanya dibuat dalam bentuk cetak. 


\section{Efficiency (Efisiensi)}

Tidak dapat membuat informasi atau laporan dalam waktu bersamaan.

6. Service (Layanan)

Belum ada layanan yang digunakan untuk memudahkan dalam penentuan produk yang paling laku di bengkel Man Motor.

\section{B. Analisa Kebutuhan}

Dalam menganalisis kebutuhan untuk mengembangkan sebuah sistem, maka diperlukan sebuah pemodelan. Pemodelan yang digunakan yaitu usecase. Berikut ini merupakan gambar diagram Use Case sistem yang diusulkan pada Man Motor. Untuk desain use casenya bisa dilihat pada Gambar 1 .

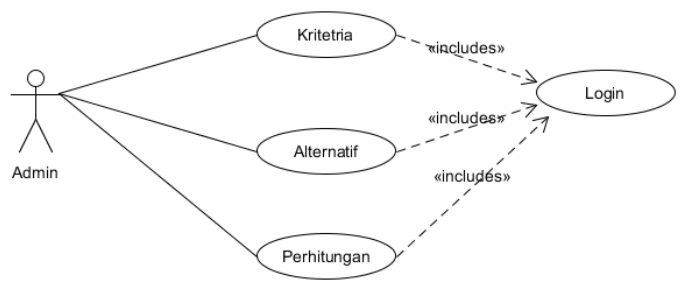

Gambar 1. Use case sistem yang dirancang

\section{HASIL DAN PEMBAHASAN}

\section{A. Desain Sistem}

Activity diagram berfungsi untuk memperlihatkan interaksi antara pengguna dengan sistem. Hal yang harus dilakukan oleh pengguna sebelum mengakses sistem yaitu melakukan login. Setelah berhasil login maka pengguna dapat melihat proses untuk menentukan produk mana yang paling laku atau banyak penjualananya.
Gambar 2. Activity dari sistem yang dirancang

\section{B. Kebutuhan Fungsional}

Kebutuhan fungsional berfungsi untuk memperlihatkan layanan apa saja yang disedikan oleh sistem. Untuk mengetahui kebutuhan fungsional sistem yang akan dibuat bisa dilihat di Tabel 1 .

Tabel 1. Kebutuhan fungsional sistem

\begin{tabular}{|c|c|c|c|}
\hline No & Kode Fungsi & Nama Fungsi & Deskripsi \\
\hline 1 & SPK-U-001 & Login & $\begin{array}{l}\text { Fungi yang } \\
\text { digunakan oleh } \\
\text { user untuk } \\
\text { mengakses sistem. }\end{array}$ \\
\hline 2 & SPK-U-002 & Kriteria & $\begin{array}{l}\text { Fungsi yang } \\
\text { digunakan oleh } \\
\text { user untuk } \\
\text { menambah, } \\
\text { mengubah, } \\
\text { mengahapus dan } \\
\text { melihat kriteria. }\end{array}$ \\
\hline 3 & SPK-U-003 & Alternatif & $\begin{array}{l}\text { Fungsi yang } \\
\text { digunakan oleh } \\
\text { user untuk } \\
\text { menambah, } \\
\text { mengubah, } \\
\text { mengahapus dan } \\
\text { melihat } \\
\text { alternative. }\end{array}$ \\
\hline 4 & SPK-U-004 & Perhitungan & $\begin{array}{l}\text { Fungsi yang } \\
\text { digunakan untuk } \\
\text { mencari produk } \\
\text { paling laku } \\
\text { menggunakan } \\
\text { metode TOPSIS }\end{array}$ \\
\hline
\end{tabular}

\section{Kebutuhan Non-Fungsional}

Kebutuhan Non-Fungsional adalah kebutuhan yang mengambarkan prilaku dari sistem. Untuk mengetahui kebutuhan non-fungsional sistem yang akan dibuat bisa dilihat di Tabel 2 .

Tabel 2. Kebutuhan non-fungsional sistem

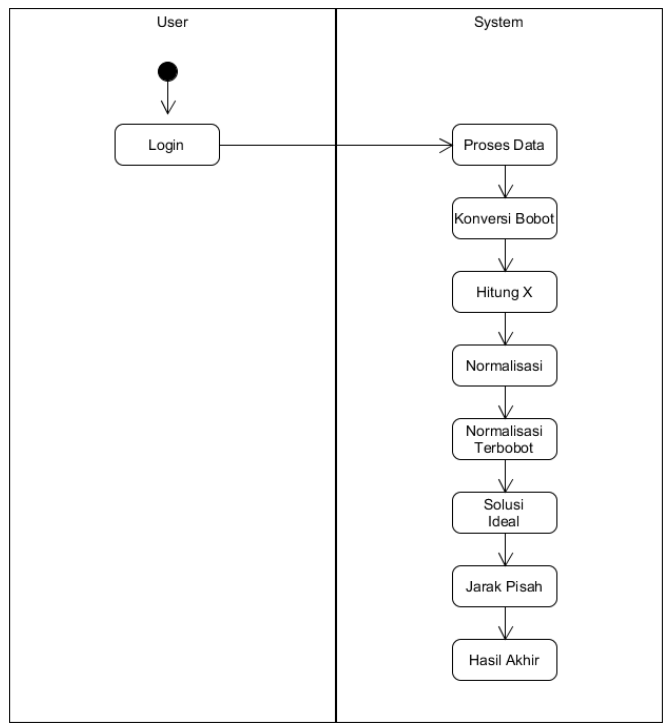

Kode Fungsi $\quad$ Nama Fungsi $\quad$ Deskripsi

\begin{tabular}{|c|l|l|l|}
\hline No & Kode Fungsi & Nama Fungsi & \multicolumn{1}{c|}{ Deskripsi } \\
\hline 1 & SPK-U-001 & Portability & $\begin{array}{l}\text { Sistem dapat } \\
\text { berjalan di sistem } \\
\text { operasi apapun, } \\
\text { baik itu di linux, } \\
\text { windows maupun } \\
\text { macOS. Serta } \\
\text { dapat diakses } \\
\text { menggunakan } \\
\text { browser apapun } \\
\text { seperti google } \\
\text { crome atau } \\
\text { mozila. }\end{array}$ \\
\hline 2 & SPK-U-002 & Avaibility & $\begin{array}{l}\text { Sistem dapat } \\
\text { diakses kapan } \\
\text { saja dan dimana } \\
\text { saja. Dengan } \\
\text { syarat koneksi } \\
\text { internet ada. }\end{array}$ \\
\hline 3 & & & $\begin{array}{l}\text { Sistem bisa } \\
\text { berkerja 24 jam } \\
\text { secara penuh dan }\end{array}$ \\
\hline & & & \\
\hline
\end{tabular}


ISSN 2085-4579

\begin{tabular}{|c|l|l|l|}
\hline & & & $\begin{array}{l}\text { data bisa berubah } \\
\text { kapan saja. }\end{array}$ \\
\hline 4 & SPK-U-004 & Security & $\begin{array}{l}\text { Semua informasi } \\
\text { yang ada harus } \\
\text { aman dari } \\
\text { pencurian data. }\end{array}$ \\
\hline
\end{tabular}

\section{MANMOTOR}

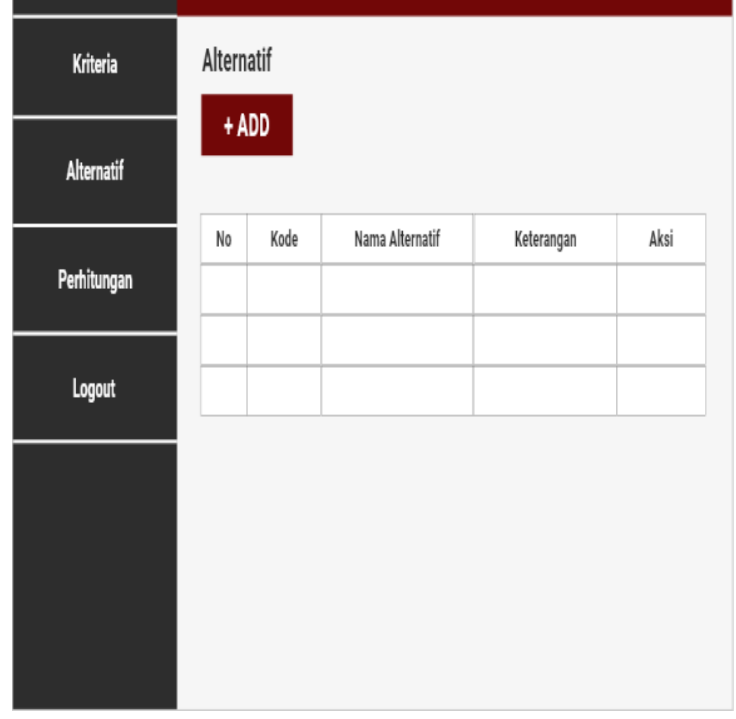

\section{Desain User Interface}

D.1 Halaman Kriteria

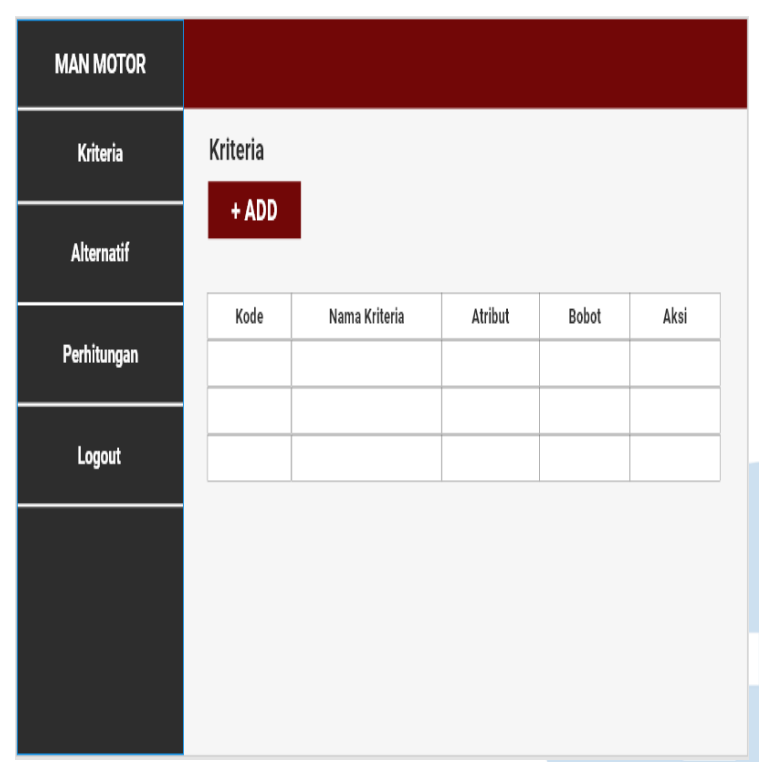

Gambar 3. Halaman kriteria

\section{Gambar 3. Halaman alternatif}

Gambar 4. Merupakan tampilan dari halaman alternatif. Disini pengguna dapat melakukan penambahan, penghapusan, mengubah dan melihat alternatif.

\section{D.3 Halaman Perhitungan}

Gambar 3 merupakan gambar untuk halaman kriteria. Disini pengguna bisa menambah, menghapus, mengubah dan melihat kriteria.

D.2 Halaman Alternatif
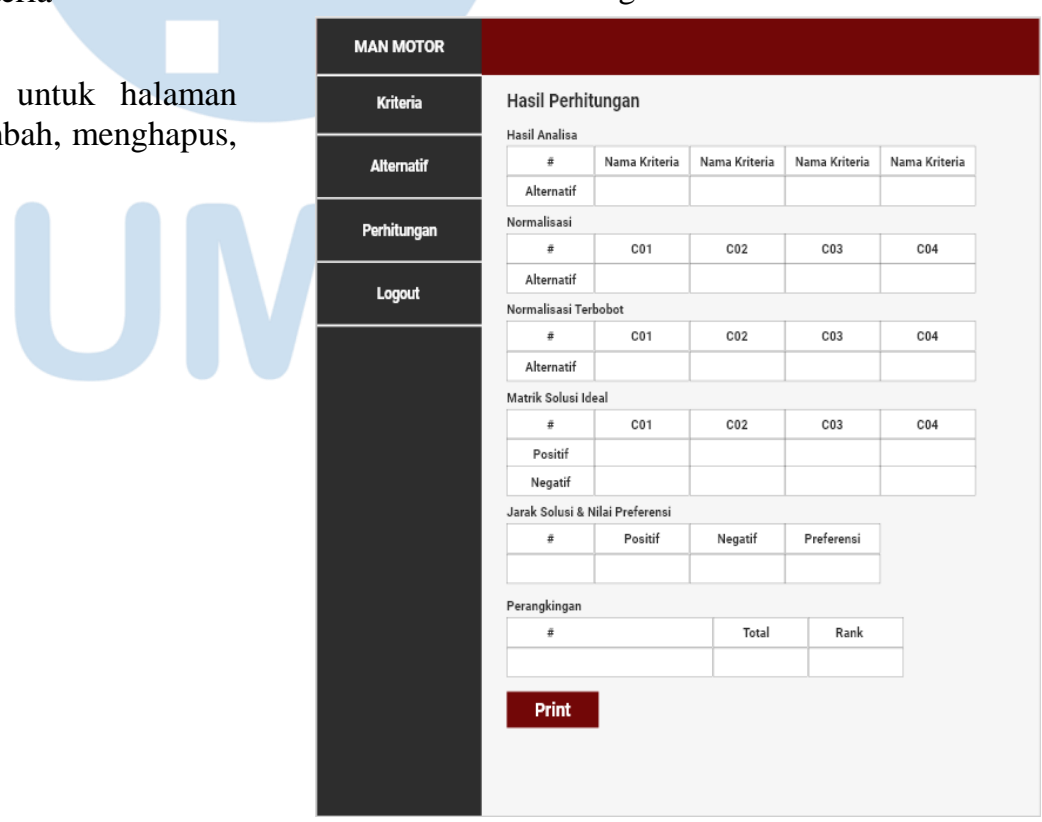

Gambar 5. Halaman perhitungan

Gambar 5 merupakan tampilan dari halaman untuk perhitungan produk terlaris di Bengkel Man Motor dengan menggunakan metode TOPSIS. 


\section{SIMPULAN}

Bagian Berdasarkan hasil perancangan website untuk penentukan produk paling banyak terjual di bengkel Man Motor dengan metode TOPSIS, maka dapat diambil beberapa kesimpulan yaitu:

1. Sistem yang dirancang memiliki fungsi utama yaitu untuk menentukan produk mana yang paling sering terjual di bengkel Man Motor.

2. Untuk membuat sebuah website diperlukan bahasa pemrogramman. Bahasa pemrogramman yang digunakan adalah PHP dan MySQL sebagai aplikasi untuk pengelolaan basis data.

\section{DAFTAR PUSTAKA}

[1] F. and S. D. H. Permana, "Sistem Penunjang Keputusan Pemilihan Sekolah Menengah Kejuruan Teknik Komputer Dan Jaringan Yang Terfavorit Dengan Menggunakan MultiCriteria Decision Making," J. Teknol. Inf. dan Ilmu Komput., vol. 2, no. 1, p. 11, 2015, doi: 10.25126/jtiik.201521123.

[2] E. Turban, J. E. Aronson, and T.-P. Liang, "Decision Support Systems and Intelligent Systems (Edisi Bahasa Indonesia)." p. 697, 2005.

[3] Sriani and R. A. Putri, “Analisa Sistem Pendukung Keputusan Menggunakan Metode Topsis Untuk Sistem Penerimaan Pegawai Pada Sma Al Washliyah Tanjung Morawa," J. Ilmu Komput. dan Inform., vol. 02, no. April, pp. 40-46, 2018.

[4] M. Marbun and B. Sinaga, Buku Ajar Sistem Pendukung Keputusan Penilaian Hasil Belajar | 1 STMIK Pelita Nusantara Medan, no. April. 2018.

[5] A. N. Fitriana, H. Harliana, and H. Handaru, "Sistem Pendukung Keputusan Untuk Menentukan Prestasi Akademik Siswa dengan Metode TOPSIS," Creat. Inf. Technol. J., vol 2, no. 2, p. 153, 2015, doi: 10.24076/citec.2015v2i2.45.

[6] S. O. K. Reflin Yadi, Muhammad Sobri, "Implementasi metode topsis untuk menentukan karyawan terbaik di pt.kfc cabang demang," J. Binadarma, pp. 1-9, 2015.

[7] N. Nahlah, A. Amiruddin, and F. Amansyah, "Perancangan Website Sekolah pada SDN 103 Kabupaten Sinjai sebagai Salah Satu Sarana Pembelajaran Online dan Penyajian Informasi," INTEK J. Penelit., vol. 4, no. 2, p. 92, 2017, doi: 10.31963/intek.v4i2.149.

[8] B. Prasetyo, T. J. Pattiasina, and A. N. Soetarmono, "Perancangan dan Pembuatan Sistem Informasi Gudang (Studi Kasus: PT. PLN (Persero) Area Surabaya Barat)," Teknika, vol. 4, no. 1, pp. 12-16, 2015, doi: 10.34148/teknika.v4i1.30.

[9] D. Wira, T. Putra, and R. Andriani, "Unified Modelling Language ( UML ) dalam Perancangan Sistem Informasi Permohonan Pembayaran Restitusi SPPD," vol. 7, no. 1, 2019.

[10] Haviluddin, "Memahami Penggunaan UML ( Unified Modelling Language )," Memahami Pengguna. UML (Unified Model. Lang., vol. 6, no. 1, pp. 1-15, 2011, [Online]. Available:

https://informatikamulawarman.files.wordpress.com/2011/10/ 01-jurnal-informatika-mulawarman-feb-2011.pdf. 